\title{
Factors Influencing Property Owners' Attitudes toward Different Orientations of Sustainability
}

\author{
Huili Hao ${ }^{1}$, Jeffery M Hill ${ }^{1} \&$ Hunter Regan Prichard ${ }^{1}$ \\ ${ }^{1}$ Department of Environmental Sciences, University of North Carolina Wilmington, United States \\ Correspondence: Huili Hao, Department of Environmental Sciences, University of North Carolina Wilmington, \\ United States. E-mail: haoh@uncw.edu
}

Received: May 7, 2018

doi:10.5539/jsd.v11n5p83

\author{
Accepted: August 1, $2018 \quad$ Online Published: September 28, 2018 \\ URL: https://doi.org/10.5539/jsd.v11n5p83
}

\begin{abstract}
The southeastern United States is well-known for its natural beauty, warm year-round climate, and vacation and outdoor recreational opportunities. This study explores and compares factors influencing property owners' attitudes toward different scales of sustainability in three coastal counties in North Carolina. In this region, tourism is the major economic driver, with second homes comprising nearly $40 \%$ of the total single-family housing stock. The research questions of this study then are: 1) Which factors influence property owners' attitudes toward sustainable tourism development? 2) Does residential status (full-time residents vs. second-home owners) best predict property owners' attitudes toward different scales/orientations of sustainability? 3) Which variables most contribute to predicting property owners' attitudes toward different scales/orientations of sustainability? A total of 1,278 respondents were surveyed concerning their perceptions of sustainable development, satisfaction with community life, and attitudes toward tourism and second-home development. Factor analyses were conducted to identify three different orientations of sustainability as identified by the researchers: operational-oriented sustainability, community-oriented sustainability, and normative-oriented sustainability. Multivariate regression analyses were used to identify and compare factors which have significant influences on attitudes toward orientations of sustainability among different types of property owners. The study results are intended to inform decision-making that will contribute to the long-term economic, environmental, and socio-cultural sustainability of these counties.
\end{abstract}

Keywords: sustainability, sustainable perceptions, property owners, coastal tourism, economy, sense of place

\section{Introduction}

Nature-based beauty and abundant recreational opportunities make many coastal destinations highly desirable places to live, vacation, and purchase a second home. As coastal communities and tourism destinations continue to experience associated development, stakeholders have come to realize the importance of balancing growth with protecting social, environmental, and economic resources and values. Sustainable development in tourism-based economies is particularly beneficial in maintaining the long-term economic viability of the industry while conserving the natural environment and preserving socio-cultural integrity. A clear understanding of residents' support for sustainable tourism development is a critical step in effective planning and management. Research measuring resident attitudes toward sustainable development is abundant, but few studies include both full-time residents and second-home owners. Second-home owners make an investment in the community, often in high-tourism locations, and may have different views and values when compared to full-time residents on topics such as sustainable development (Anabestani, 2014). Thus, incorporating this population into studies focused on tourism locations is important. In addition, studies investigating attitudes of residents typically focus on the degree of support for sustainable development. Little research examines perceptions of different orientations/scales of sustainability and factors influencing these perceptions. This study seeks to fill these gaps in the literature by addressing two objectives: 1) explore different orientations of sustainability based on property owners (both full-time residents and second home property owners; and 2) investigate and compare factors influencing property owners' attitudes toward different orientations of sustainability in three North Carolina coastal communities: Brunswick, Currituck, and Pender counties. The economies of these counties rely heavily on the tourism industry, with approximately $\$ 861.3$ million in visitor spending in these regions in 2016 (United States Travel Association, 2017). Property owners, both full-time and second-home owners, are included in this 
study to investigate their attitudes towards sustainable development. Understanding the attitudes of property owners may have important implications for sustainable development efforts; therefore, understanding the factors that influence these attitudes is critical to decision-making and the long-term economic, environmental, and socio-cultural sustainability of the area.

The following three research questions were addressed in this study:

1) Are there different scales/orientations of sustainability that underlie property owners' attitudes toward sustainable development?

2) What are the variables that contribute to predicting property owners' support for attitudes toward different scales/orientations of sustainability?

3) Does residential status (full-time resident vs. second-home owner) predict property owners' attitudes toward different scales/orientations of sustainability?

The findings associated with these research questions may inform coastal communities that are endeavoring to incorporate different scales of sustainable actions into their community planning processes. This study may also contribute to the literature by providing a greater understanding of the need to for second-home property owner involvement in community development.

\section{Literature Review}

\subsection{Sustainable Development Perceptions}

Sustainable development was first conceptualized by the United Nation's World Commission on the Environment and Development in the Brundtland Report as "development that meets the needs of the present without compromising the ability of future generations to meet their own needs" (1987, p. 204). Since then, it has influenced the framework for sustainable growth, and its goals have been expounded upon in subsequent United Nations agendas to target equality, equity, and well-being, as well as sustainable economic growth, consumption patterns, and environmental conservation (United Nations General Assembly, 2015).

Resident attitudes towards sustainable development are crucial to communities' success, viability, and management. Many studies have focused on resident perceptions of sustainable development, particularly in areas reliant on tourism economies or currently experiencing economic growth (Chen, 2015; Lee, 2013; Muresan et al., 2016; Su, Chang, \& Yeh, 2017; Timur \& Getz, 2009; Zhu, Liu, Li, \& Wang, 2017). Factors that affect residents' perceptions of sustainable development include demographics, environmental attitudes, perceived impacts of development, and community-based factors.

\subsubsection{Demographics}

The impact of demographic factors varies between studies. Age and gender have an inconsistent relationship with perceptions, while education level and employment in the tourism sector were significantly related to residents' perceptions of sustainable tourism development in a study of the Lenggong Valley in Malaysia (Muresan et al., 2016; Rasoolimanesh \& Jaafar, 2017). Other demographics of these residents, such as income level or whether the respondent was native to the area, had no significant effect on their attitudes (Rasoolimanesh \& Jaafar, 2017). The overall impact of various demographic factors is inconclusive, and more research is needed to make broader conclusions regarding their role in shaping residents' perceptions of sustainable development.

\subsubsection{Environmental Attitudes}

Assessing the environmental attitudes of residents can be useful in determining the causes of shifts in resident perceptions of sustainable development. However, in several cases, the measurement of these attitudes varies widely. They range from scales such as the New Ecological Paradigm, which measures the level of a person's pro-ecological worldview, to other methods that seek to understand whether the respondent has ecocentric or anthropocentric views or measure their attitudes towards environmental sustainability (Choi \& Murray, 2010; Su et al., 2017; Xu \& Fox, 2014). When measured using the New Ecological Paradigm or an anthropocentric/ecocentric scale, environmental attitudes were found to be significantly related to perceptions of sustainable development ( $\mathrm{Su}$ et al., 2017; Xu \& Fox, 2014). However, attitudes toward environmental sustainability did not exhibit a significant relationship to residents' support for tourism development (Choi \& Murray, 2010).

\subsubsection{Perceived Impacts}

The influence of perceived impacts of sustainable development is one of the most well-studied aspects of 
sustainable development support. It has been used to predict residents' support and attitudes toward sustainable tourism development. In some studies, it serves as a mediating factor between other variables and support for sustainable tourism development (Choi \& Murray, 2010; Lee, 2013; Zhu et al., 2017).

Residents' perceptions of the impact of sustainable development are typically significant predictors of their support and attitudes toward it (Choi \& Murray, 2010; Lee, 2013; Muresan et al., 2016; Yu, Chancellor, \& Cole, 2011; Zhu et al., 2017). Impacts can be understood as costs and benefits of development. These costs and benefits can range from social, economic, environmental, and institutional impacts, as well as being personal or collective (community-based) impacts (Lee, 2013; Zhu et al., 2017). Common predictors of support for sustainable development include perceived economic benefits, in the form of new businesses and employment, and improvements to residents' quality of life through benefits associated with new infrastructure construction (Muresan et al., 2016; Yu et al., 2011). The perceived costs of increased development are negative impacts on the environment, which then may negatively influence residents' perceptions of development (Muresan et al., 2016).

In addition, the mediating effect of perceived benefits and costs on attitudes toward sustainable development has been studied in several contexts. The perceived impacts of tourism may be influenced by other factors, such as community involvement and attachment, as well as tourism development potential (Lee, 2013; Zhu et al., 2017). Community involvement, attachment, and measures of sense of place are shown to be positively related to perceived benefits and a greater support for tourism development (Lee, 2013; Zhu et al., 2017). The mediating effect of perceived costs varies (Lee, 2013; Zhu et al., 2017), and the scale of the impacts, collective or personal, affects its influence on tourism support.

\subsubsection{Community Relationships}

The relationship between respondents and their communities indicates their level of involvement, attachment, and overall sense of place associated with the area and its community. This relationship is important to understanding whether residents' attitudes toward sustainable development change as a stronger sense of place, level of community involvement, and attachment develop (Lee, 2013; Zhu et al., 2017). However, this relationship is not universally supported in the literature. For example, Choi and Murray (2010) found that increased community involvement related to more negative views of development. However, the relationships between sustainable development and a greater attachment and sense of place are more consistently supported in the literature (Choi \& Murray, 2010; Lee, 2013; Zhu et al., 2017).

\subsection{Scales / Orientations of Sustainability}

Differences in residents' attitudes towards sustainable development are rarely addressed in the literature beyond a positive and negative dichotomy. One study on tourism stakeholders, including the host community, used principle component analysis to understand the stakeholder's perceptions of the goals of sustainable tourism development (Timur \& Getz, 2009). In this study, three factors related to stakeholder perceptions of sustainable tourism development goals arose, which focused on issue-oriented growth, experience-oriented growth, and industry-oriented growth. Issue-oriented growth targeted environmental and social sustainability, as well as community involvement, while experience-oriented growth was involved in expanding the tourism industry and ensuring visitor satisfaction. Finally, industry-oriented growth focused on the long-term economic viability of the tourism economy (Timur \& Getz, 2009). Each of these factors addresses different concerns of long-term issues associated with the environmental, social, and economic aspects of sustainability. The present study investigates the attitudes toward sustainable development of permanent residents and second-home owners in three coastal counties in North Carolina. Demographic factors, support of tourism development, perceived costs of tourism, residential status, length of residency, sense of place, and satisfaction with government, economy, and community are incorporated into the model of attitudes toward sustainable development. The resulting attitudes were further factored into three groups of sustainable views: operational-oriented, normative-oriented, and community-oriented sustainability.

\section{Method}

\subsection{Study Area}

This study used a mixed-method approach, including online and paper surveys, as well as questionnaires administered through telephone interviews, to examine property owners' attitudes toward sustainable development in three North Carolina counties: Brunswick, Currituck and Pender. These counties were selected based on their proximity to the coast, tourism and recreation assets, and high concentration of vacation homes. They are located along the coast of the Atlantic Ocean and known for their natural beauty, warm year-round climate, and exceptional vacation and outdoor recreational opportunities. The economies of these counties are 
tourism-dependent, with approximately $\$ 861.3$ million in visitor spending in these regions in 2016. Additionally, the tourism industry in these counties directly generated 8,510 jobs, resulted in approximately $\$ 162$ million in payroll and over $\$ 92$ million in state and local tax revenue (United States Travel Association, 2017). Vacation homes in these three counties, an important component of the tourism economy, encompass nearly $40 \%$ of the single-family housing stock.

\subsection{Sampling Procedures}

The Geographic Information System (GIS) Tax Record provides a list of housing stock for each of the study counties. We compared each single-family property's physical address and its tax bill mailing address. Second-home property owners were identified as those who own property in the study area which was not their primary residence. Thus, the property ownership differentiation was based upon the address where their property bill was sent. The randomly selected sample included 7,192 second home property owners and 7,395 full-time/permanent property owners. Data collection was initiated through a cover letter being sent to the members of the sample inviting them to visit the study's website and complete the survey. Participants had the option of completing a hardcopy survey or taking the survey through a telephone interview. During the survey period, two reminder cards and two reminder phone calls were made to those who had not yet completed the survey. A total of five contacts were therefore made within the six months of the sampling timeframe. We received 1,278 useable, completed questionnaires (696 from permanent residents and 785 from vacation home owners), which yielded a response rate of approximately $9 \%$.

\subsection{Participant Characteristics}

Of the 1,278 respondents, $86.3 \%$ of second-home owners and $76.2 \%$ of full-time residents were between 45 and 74 years of age. Over $90 \%$ of the comparison groups were Caucasian and over $50 \%$ of each group were male. More than $75 \%$ of the second-home owners and $50 \%$ of the full-time home owners earned at least a college degree. When annual household income levels reached $\$ 100,000$ or above, second-home owners exhibited greater income at all levels. For instance, within the $\$ 100,000$ to $\$ 199,999$ income range, $36 \%$ of the respondents were second-home owners compared to $23.7 \%$ of resident-home owners. Over $40 \%$ of both groups reported being retired while $51.2 \%$ of second-home owners and $41.6 \%$ of full-time residents reported they no longer had children at home.

\subsection{Measurement and Factor Analysis}

\subsubsection{Dependent Variables}

Given the greater focus on incorporating sustainability as a critical element within the travel and tourism industry, as well as the tendency of a growing number of individuals to adopt sustainable practices within their daily lives, many tourism destinations recognize the importance of being branded as socially and environmentally responsible. In this study, respondents were asked about their perceptions of the importance of fifteen sustainable actions to the long-term viability of their county's tourism development using a 5-point Likert Scale ranging from 1 (not at all important) to 5 (very important). Sustainable practices indicators were developed from previous studies (Choi \& Murray, 2010; Hao, Long, \& Hoggard, 2014; Yu et al., 2011). A list of the 15 sustainable practice indicators is provided in Table 1. Principal Component Analysis (PCA) was performed to identify the themes/factors underlying a series of fifteen variables measuring sustainable actions. The Kaiser-Meyer-Oklin Measure of Sampling Adequacy (KMO) tests the quality of the correlations between variables in order to be able to continue with the factor analysis. An acceptable factor analysis requires a KMO value of 0.6 or larger (Tabachnick \& Fidell, 1989). The KMO value was 0.93 and the Bartlett's test was significant $(\mathrm{p}=.000)$, indicating that the sampling for PCA was adequate and necessary. The factor loading values that show the correlations between variables and factors are used to detect whether the set of variables can be represented by a certain factor or theme. Based on the factor loadings for each variable as shown in Table 1, three themes were revealed, which explained $68 \%$ of the variance. These three themes represented three dimensions of sustainability: operational-orientated, normative-oriented, and community-oriented sustainability, which serve as three dependent variables. An average scale for each dimension of sustainability was calculated. 
Table 1. Principle Component Analysis for property owners' perceptions of the importance of sustainable development in their community

Factored Items Factor Loadings

\section{Operational-oriented sustainability}

Reducing and managing greenhouse gas emissions

Managing, reducing, and recycling solid waste

Reducing consumption of freshwater

Managing waste water

Being energy efficient

Purchasing from companies with certified green practices

Training and educating employees on sustainability practices

\section{Normative-oriented sustainability}

Conserving the natural environment

Protecting our community's natural environment for future generations

Protecting air quality

Protecting water quality

\section{Community-oriented sustainability}

Reducing noise

Preserving culture and heritage

Providing economic benefits from tourism to locals

\subsubsection{Independent Variables}

Independent variables included: a) socio-demographic variables; b) length of property ownership; c) property owners' satisfaction level with different dimensions of community life; d) property owners' perceptions of tourism's negative impacts; e) support for further tourism development; and f) community sense of place. Property owner's negative perceptions of tourism's had a high correlation with support for the further tourism development factor, which was not included in the regression model.

\section{$\underline{\text { Socio-demographic Variables }}$}

Gender, age, duration of property ownership, annual household income, and education level data were used to understand the demographic characteristics of the respondents. Age was categorized into 10-year intervals, with the exception of the first two and the last groupings: 25 and under, 26 to 34, and 75 and over. Education level contained six categories: (1) less than high school, (2) high school or GED, (3) 2-year college or technical school, (4) some college, but no degree, (5) 4-year college, and (6) postgraduate. Annual household income was coded into ten categories ranging from 1 (less than $\$ 15,000)$ to 10 (\$400, 000 and over). Duration of property ownership was determined based upon the number of years a respondent resided (for full-time residents) or owned a second-home property (for second-home owners) in the community.

\section{Satisfaction Level with Community Life Factors}

To examine property owners' satisfaction level with different dimensions of community life, 24 statements were adopted using a 5-point Likert scale for each statement $(1=$ highly dissatisfied to $5=$ highly satisfied $)$. These statements were selected from previous literature (Hao, Long, \& Kleckley, 2011) and were verified by members of focus groups conducted in each of the three counties. A series of PCA were conducted to assess the underlying dimensions of the 24 variables. Six factors emerged, including land use, economy and jobs, government services, cultural offerings, infrastructure, and quality of life, and were validated by their factor loading values and percentage of variance explained, as shown in Table 2. The KMO measure of sampling adequacy values was high $(>0.6)$ and the Bartlett's test was significant for all six factors, suggesting that the PCA analyses were appropriate and necessary. An average scale was computed for each of the six community life factors. 
Table 2. PCA for property owners' satisfaction level with community life

\begin{tabular}{lc}
\hline Factored Items & Factor Loadings \\
\hline Land Use & \\
The amount of tourism commercial development & 0.832 \\
The amount of non-tourism commercial development & 0.800 \\
The amount of residential development & 0.762 \\
Economy and Jobs & \\
Cost of living compared to other coastal communities & 0.668 \\
Employment opportunities & 0.768 \\
Number of tourism businesses & 0.741 \\
Government Services & \\
Quality of local public education system & 0.556 \\
Educational offerings for adults & 0.642 \\
Crime prevention & 0.749 \\
Fire and emergency services & 0.731 \\
Cleanness and upkeep of the county & 0.667 \\
Cultural offerings & \\
Number of cultural offerings & 0.903 \\
Mix of cultural offerings & 0.918 \\
Promotion of cultural and historical resources & 0.865 \\
Interactions between visitors and property owners & 0.658 \\
Infrastructure & \\
Availability of public parking during tourist season & 0.630 \\
The quality of parks, greenways and bike lanes & 0.658 \\
The management of traffic generated by tourists & 0.713 \\
Availability of public sewer system & 0.663 \\
Management of storm water runoff & 0.700 \\
Quality of life & \\
The range of housing styles and designs & 0.707 \\
Affordability of work force housing & 0.627 \\
Availability of quality healthcare service & 0.709 \\
\hline & 0.730 \\
\hline Availability of quality recreational opportunities practices & \\
\hline
\end{tabular}

\section{Negative Impacts of Tourism and Support for Further Tourism Development}

Property owners' opinions of tourism's negative impacts and support for further tourism development were captured by statements using a 5 -point Likert scale $(1=$ strongly disagree to $5=$ strongly agree $)$. These variables were selected from literature in the tourism and travel field (Choi \& Murray, 2010; Hao, Alderman, \& Long, 2013; Lee, 2013; Zhu et al., 2017) and verified by community members in each of the three counties through focus groups. Two composite average scales were computed for the perceived negative impacts of tourism and support for further tourism development variables based on the results from PCA as shown in Table 3. The KMO statistic was high and the Bartlett's test was significant $(p=0.000)$ for both the negative impacts of tourism factor and support for further tourism development factor, suggesting PCA analyses were necessary and appropriate. 
Table 3. PCA for property owners' perceptions on tourism's negative impacts and support for further tourism development

Dimension and Factored Items Factor Loadings

\section{Tourism's Negative Impacts}

My quality of life has deteriorated because of tourism

Recreational resources are overused by tourists

There is overcrowding due to tourism development

Tourism increases traffic problems

Tourism increases the amount of crime in our community

Tourism development unfairly increases real estate costs

Tourism in our County is growing too fast

\section{Support for Further Tourism Development}

Tourism holds great promise for our County's future

I support tourism having a vital role in this county

Our county should plan and manage tourism's growth

Local government should provide tax incentives to encourage private development in tourism

I support new tourism facilities that will attract more tourists to my community

We need to take a long-term view when planning for tourism development

Tourism development should embrace the values of all community residents

0.505

Tourism should be developed in harmony with the natural environment

0.521

\section{Community Sense of Place}

The community sense of place factor was measured by three place-attachment variables: a) I feel that I can really be myself here; b) I really miss it when I am away too long; and c) this is the best place to do things I enjoy. The loading value for each of the three variables was higher than 0.7 , as shown in Table 4 . Approximately $70 \%$ of the variance in the three items was explained by the community sense of place factor. The KMO statistic was high and the Bartlett's test was significant, indicating that PCA was appropriate and necessary. An average scale was created for the community sense of factor.

Table 4. PCA for property owners' sense of place

\begin{tabular}{lc}
\hline Dimension and Factored Items & Factor Loadings \\
\hline Sense of Place & \\
I feel that I can really be myself here & 0.795 \\
I really miss it when I am away too long & 0.859 \\
This is the best place to do the things I enjoy & 0.839 \\
\hline
\end{tabular}

\section{Results and Discussion}

Multivariate regression analysis was used to investigate factors that contribute to influencing property owners' support for attitudes toward different scales / orientations of sustainability. This statistical approach assumes that: (1) the relationships between dependent and independent variables are linear; (2) the observations in the dependent variable are independent of one another; (3) the data are normally distributed; (4) there is no multicollinearity among independent variables; and (5) the variance of residuals is the same across all values of the independent variables (homoscedasticity) (Tabachnick \& Fidell, 2007). The values of variance inflation factor (VIF) were used to detect multicollinearity problems. The VIF value for each independent variable is equal or less than 2.0, suggesting that a significant relationship exists among independent variables (Meyers, Gamst, \& Guarino, 2006). Examination of other assumptions for the multivariate regression analysis showed: (1) 
linearity between dependent and independent variables; (2) independence of observations in the dependent variables; (3) normality; and (4) homoscedasticity.

\subsection{Multivariate Regression Analysis: Operational-Oriented Sustainability}

Results from multivariate regression analysis for operational oriented sustainability revealed that $17 \%$ of the variance in the dependent variable was explained by all the independent variables. The model is statistically significant $(\mathrm{F}=14.01)$. Table 5 demonstrates that the parameter estimates of the multivariate regression model in which property owners' perceptions of operational-oriented sustainability were a function of socio-demographic characteristics, factors related to property owners' satisfaction level with six dimensions of community life (land use, economy and jobs, government services, cultural offerings, infrastructure, and quality of life), property owners attitude toward tourism's negative impacts on their communities, their support for further tourism development, sense of place, as well as residential status. Two of the five socio-demographic characteristics, gender and annual household income, had a significant negative relationship with property owners' perceptions of operational-oriented sustainability. Male respondents were less likely to rate operational-oriented sustainable practices as important in their community's development than female respondents. People with higher household income were less likely to believe that operational-oriented sustainable practices are important. This finding is different from that of previous studies where income level had no significant relationship with sustainable attitudes (Rasoolimanesh \& Jaafar, 2017).

Property owners' satisfaction level with community life, economy and jobs, as well as government services had a significant relationship with property owners' perceptions of operational-oriented sustainability. Their relationships are in the positive direction. Specifically, people who were more satisfied with their community's economic conditions and job opportunities tended to be more supportive of operational-oriented sustainable practices. Four other factors related to satisfaction with community (land use, culture offerings, infrastructure, and quality of life) did not act as significant predictors of property owners' perceptions of operational-oriented sustainability. These results are only partially consistent with Assante, Wen, and Lotting (2012), which suggest that overall community satisfaction does not affect sustainable tourism development attitudes. Tourism's negative impacts and support for future tourism development are significant predictors of the dependent variable, as well. Their relationships were found to be positive. Those who supported future tourism development were more likely to support operational-oriented sustainable practices. Those who focused on tourism's negative impacts, on the contrary, were more likely to view operational-oriented sustainable practices as important. This result contradicts the relationship identified by Muresan et al. (2016) that tourism's negative impacts negatively influences residents' perceptions of development.

The surprising finding of a lack of a relationship between community sense of place and operational-oriented sustainability contradicts the relationship identified by Zhu et al. (2017) and Lee (2013) that suggested a stronger sense of place, level of community involvement, and attachment are related to a more positive view of sustainable development. Residential status (full-time residents vs. second-home owners) did not predict property owners' attitudes toward operational-oriented sustainability. This finding, likewise, contradicts Frauman and Banks (2011), who suggest that the location of residence within the county and status as permanent residents vs. second-home owners were the most influential factors pertaining to perceptions of the importance and performance of environmental, socio-economic, and socio-cultural characteristics of Watauga County, North Carolina.

\subsection{Multivariate Regression Analysis: Community-Oriented Sustainability}

Results from multivariate regression analysis for community-oriented sustainability revealed that $18 \%$ of the variance in the dependent variable was explained by all the independent variables. The model is statistically significant $(F=15.04)$. Similar to the results from operational-oriented sustainability model, as shown in Table 5 , gender and household income were negatively associated with community-oriented sustainability. These relationships are significant. Male respondents were less likely to view community-oriented sustainable practices as important in their community's development in comparison to female respondents. People with higher household income were less likely to feel that community-oriented sustainable practices are important in their community development.

Among the factors related to property owners' satisfaction level with community life, government services and quality of life play significant roles in predicting property owners' perceptions of community-oriented sustainability. Respondents who were more satisfied with the level of government services provided in their community were more likely to view community-oriented sustainable practices as important. This quality of life factor is negatively associated with community-oriented sustainability. Specifically, respondents who were less 
satisfied with the area's quality of life were more likely to support community-oriented sustainable practices. A possible explanation for this relationship could be that people who are not satisfied with the current quality of life hope that community-oriented sustainable practices could bring changes to the community that improve the community's quality of life. Four other satisfaction with community life factors (land use, economy and jobs, cultural offerings, and infrastructure) did not act as significant predictors influencing property owners' perception of community-oriented sustainability.

Tourism's negative impacts and support for future tourism development were significant predictors of the dependent variable. Those respondents who supported future tourism development were more likely to support community-oriented sustainable practices. Those who focused instead on tourism's negative impacts were more likely to view community-oriented sustainable practices as important.

Community sense of place had a positive and significant relationship with community-oriented sustainability, which suggests that highly attached property owners tend to view community-oriented sustainable practices more favorably than less-attached property owners. This finding is similar to that of Zhu et al. (2017) and Lee (2013), who suggest that a stronger sense of place, level of community involvement, and attachment are related to a more positive view of sustainable development. Residential status, however, did not predict property owners' attitudes toward community-oriented sustainability.

\subsection{Multivariate Regression Analysis: Normative-Oriented Sustainability}

Results from multivariate regression analysis for normative-oriented sustainability revealed that $16 \%$ of the variance in the dependent variable was explained by all the independent variables. The model is statistically significant $(\mathrm{F}=13.37)$. Three of the five socio-demographic characteristics, gender, income, and education level, played significant roles in predicting property owners' perceptions on normative-oriented sustainability. Similar to the previous results, gender and income still had negative relationships with normative-oriented sustainability.

Male respondents were less likely to perceive normative-oriented sustainable practices as important in comparison to female respondents. People with higher household income were less likely to feel that normative-oriented sustainable practice are important in their community development. Education was positively related to the dependent variable. People with a high level of education tended to support normative-oriented sustainable practices.

Among the factors related to property owners' satisfaction with community life, only government services significantly influenced property owners' attitudes toward normative-oriented sustainability. Respondents who were more satisfied with the level of government services provided in their community were more likely to support normative-oriented sustainable practices. Tourism's negative impacts and support for future tourism development were significant and positively-related predictors of the dependent variable as well. Those who supported future tourism development were more likely to support normative-oriented sustainable practices. Those who focused instead on tourism's negative impacts were more likely to view normative-oriented sustainable practices as important.

Community sense of place had a positive and significant relationship with normative-oriented sustainability, which suggests that highly-attached property owners tend to view normative-oriented sustainable practices more favorably than less attached property owners. This finding is similar to the work of Zhu et al. (2017) and Lee (2013), who suggest that a stronger sense of place, level of community involvement, and attachment are related to a more positive view of sustainable development. Residential status, however, did not predict property owners' attitudes toward normative-oriented sustainability. 
Table 5. Results of multivariate regression analysis

\begin{tabular}{|c|c|c|c|}
\hline Variables & $\begin{array}{c}\text { Operational-Oriented } \\
\text { Sustainability }\end{array}$ & $\begin{array}{c}\text { Community-Oriented } \\
\text { Sustainability }\end{array}$ & $\begin{array}{c}\text { Normative-Oriented } \\
\text { Sustainability }\end{array}$ \\
\hline \multicolumn{4}{|l|}{ Socio-demographics } \\
\hline Gender $^{\mathrm{a}}$ & $-0.195^{*}$ & $-0.129^{*}$ & $-0.137^{*}$ \\
\hline Age & 0.047 & -0.001 & -0.014 \\
\hline Length of owning property & 0.047 & 0.052 & 0.020 \\
\hline Income & $-0.091^{*}$ & $-0.085^{*}$ & $-0.069^{*}$ \\
\hline Education & 0.049 & -0.024 & $0.065^{*}$ \\
\hline \multicolumn{4}{|c|}{ Satisfaction with Community life } \\
\hline Land use & 0.014 & 0.035 & -0.009 \\
\hline Economy and jobs & $0.113^{*}$ & 0.055 & 0.062 \\
\hline Government services & $0.077 *$ & $0.101^{*}$ & $0.098^{*}$ \\
\hline Culture offerings & -0.061 & -0.037 & -0.069 \\
\hline Infrastructure & 0.074 & 0.032 & 0.041 \\
\hline Quality of life & -0.070 & $-0.091^{*}$ & -0.022 \\
\hline Tourism's negative impacts & $0.191 *$ & $0.235^{*}$ & $0.190^{*}$ \\
\hline Support for future TD & $0.338^{*}$ & $0.354^{*}$ & $0.321 *$ \\
\hline Sense of place & -0.011 & $0.099^{*}$ & $0.115^{*}$ \\
\hline Residential status $^{\mathbf{b}}$ & 0.018 & 0.032 & 0.003 \\
\hline Adjusted $\mathrm{R}^{2}$ & 0.171 & 0.182 & 0.162 \\
\hline F value & 14.066 (sig. 0.000$)$ & 15.039 (sig. 0.000 ) & 13.370 (sig. 0.000$)$ \\
\hline
\end{tabular}

${ }^{\mathrm{a}}$ Dummy coded: $1=$ male, $0=$ female

${ }^{\mathrm{b}}$ Dummy coded: 1 = Full-time resident property owners; $0=$ second-home property owners

*Significant at 0.05 level

\section{Conclusion}

The primary purpose of this study was to examine property owners' perceptions of different dimensions of sustainability and factors that influenced their perceptions in three North Carolina coastal communities. We sought to expand the sustainability literature and provide a different perspective by shifting the literature's attention from the traditional triple-bottom line of sustainability (economic, social, and environmental) toward new dimensions of sustainability: operational, community, and normative.

Native residents in many tourism destinations find that newcomers either moved to their neighborhoods seasonally, purchased properties for investment, or simply retired to the place they fell in love with originally as tourists themselves (Frauman \& Banks, 2011). This phenomena is particularly true in our study area, where approximately $40 \%$ of the single-family homes are owned by non-residents. Revenue from second-home construction and property taxes provides primary resources for local public services. It is almost impossible to bring about sustainable development in a tourism destination without stakeholder's understanding, input, and support (Puczko \& Ratz, 2000). As significant stakeholders, second-home property owners' input and support of sustainable development is equally important as that of local residents. While several studies contribute to the body of knowledge regarding local residents' support for sustainable tourism development, research focused on second-home owners' perceptions of sustainable tourism is still limited. In recognition of this gap in the literature, this study seeks to include both local residents and second-home owners to better understand their attitudes toward sustainable development through addressing the following three questions:

1) Are there different scales/orientations of sustainability that underlie property owners' attitudes toward sustainable development?

2) What are the variables that contribute to predicting property owners' support for attitudes toward 
different scales/orientations of sustainability?

3) Does residential status (full-time residents vs. second-home owners) predict property owners' attitudes toward different scales/orientations of sustainability?

As is frequently the case, the answers to these research questions were varied and the results both converge and diverge from the current literature on sustainability and attitudes toward sustainable development. Results from PCA for property owners' perceptions on the importance of sustainable development in their community suggested that three orientations of sustainability exist: operational-orientated, normative-oriented, and community-oriented sustainability, which is different from the traditional triple-bottom line of sustainability: social, economic and environmental.

Multivariate regression analyses were conducted to answer questions 2 and 3. The performance of these three models was then compared across the three orientations of sustainability. In the operational-oriented sustainability model, gender, income, economy and jobs, government services, and tourism's negative impacts proved to be significant factors influencing property owners' support for operational-oriented sustainable actions. In the community-oriented model, gender, income, government services, quality of life, tourism's negative impacts, support for further tourism development, and community sense of place were found to be significant factors predicting property owners' perceptions of the importance of community-oriented sustainable practices. Finally, in the normative-oriented sustainability model, gender, income, government services, tourism's negative impacts, support for future tourism development, and community sense of place proved to be significant variables that influenced property owners' attitudes toward normative-oriented sustainability. Gender, income, satisfaction with government services, and support for further tourism development were significant factors predicting all three dimensions of sustainability.

Most interesting is that residential status (full-time resident vs. second-home owners) was not significant in any of the three models, indicating that it did not predict property owners' attitudes toward any dimensions of sustainability. This contradicts the findings from Frauman and Banks' (2010) work in Watauga County, NC; one of the few in the literature that included second-home owners as one of the stakeholders when investigating sustainable development perceptions. They revealed that residential status was the most influential factor relating to perceptions of the importance and performance of environmental, socio-economic, and cultural features of the county.

As popular tourism destinations evolve from provision of general tourism products and services to desirable vacation home destinations, the amenity-rich counties and the communities within face the ongoing struggle of balancing commercial development with protecting the natural environment while maintaining community sense of place. Important planning, policy, and management issues must be addressed in order to ensure sustainable development in the host communities. The present study seeks to understand stakeholders' support for fundamental aspects of sustainable actions, thereby guiding effective planning and management. The results of this study can therefore inform planners, developers, and other community representatives in assessing support and determining specific actions for sustainable practices in their community's tourism development, and thereby facilitate citizen engagement in the future sustainability of the region.

\section{Limitations and Future Research}

As with all research, this study has limitations. Possibly the most surprising finding of this study is that residential status did not predict any dimensions of sustainability. This finding may be associated with the reasons to purchase second-home properties and/or reside in the communities. It is possible that homeowners who chose the community's natural environment for vacation, recreation, and other leisure activities may have different attitudes toward sustainable strategies than those who use their properties for financial investment, such as a rental businesses. In addition, some of the "local full-time residents" were possibly second-home owners first, but retired to the community permanently and became "full-time property owners." Their sustainable attitudes may prove to be different from those who are native to the area. Future research may therefore be focused upon delineating property owners based on their motivations to purchase property, as well as more detailed residential characteristics. To this end, it may be beneficial to perform multivariate regression analysis independently for different types of property owners.

Another area of limitation of this study involves the model performance. The relatively low $\mathrm{R}^{2}$ indicates that more relevant independent variables may have improved the model fit. For instance, Currituck, Pender and Brunswick counties are quite different in their stages of tourism development. Residents of more tourism-intensive communities may have different attitudes than those in more isolated and less tourism-dependent areas. Hence, adding variables to the equation related to "place characteristics" may enrich 
the model and increase its predictive power.

\section{Acknowledgments}

This research was supported by North Carolina Sea Grant.

\section{References}

Anabestani, A. (2014). Effects of second home tourism on rural settlements development in Iran (case study: Shirin-Dareh Region). International Journal of Culture, Tourism, and Hospitality Research, 8(1), 58-73. https://dx.doi.org/10.1108/IJCTHR-11-2012-0084

Assante, L. M., Wen, H. I., \& Lotting, K. (2012). An empirical assessment of residents' attitudes for sustainable tourism development: A case study of O'ahu, Hawaii. Journal of Sustainability and Green Businesses, 1, 127.

Chen, J. (2015). Tourism stakeholders' attitudes toward sustainable development: A case in the Arctic. Journal of Retailing and Consumer Services, 22(1), 225-230. https://dx.doi.org/10.1016/j.jretconser.2014.08.003

Choi, H. C., \& Murray, I. (2010). Resident attitudes toward sustainable community tourism. Journal of Sustainable Tourism, 18(4), 575-594. https://dx.doi.org/10.1080/09669580903524852

Frauman, E., \& Banks, S. (2011). Gateway community resident perceptions of tourism development: Incorporating importance-performance analysis into a limits of acceptance change framework. Tourism Management, 32(1), 128-140.

Hao, H., Alderman, D. H., \& Long, P. (2013). Homeowners' attitudes toward tourism in a mountain resort community. Tourism Geographies: An International Journal of Tourism Space, Place and Environment 16(2), 270-287. https://dx.doi.org/10.1080/14616688.2013.823233

Hao, H., Long, P., \& Hoggard, W. (2014). Comparing property owners' perceptions of sustainable tourism in a coastal resort county. Journal of Policy Research in Tourism, Leisure and Events, 6(1), 31-51.

Hao, H., Long, P., \& Kleckley, J. (2011.) Factors predicting homeowners' attitudes toward tourism: A case of a coastal resort community. Journal of Travel Research, 50(6), 627-640. https://dx.doi.org/10.1177/0047287510385463

Lee, T. H. (2013). Influence analysis of community resident support for sustainable tourism. Tourism Management, 34, 37-46. https://dx.doi.org/10.1016/j.tourman.2012.03.007

Meyers, S. L., Gamst, G., \& Guarino, A. J. (2006). Applied multivariate research: Design and interpretation. Thousand Oaks, CA: Sage.

Muresan, I., Oroian, C., Harun, R., Arion, F., Porutiu, A., Chiciudean, G., Todea, A., \& Lile, R. (2016). Local residents' attitude toward sustainable rural tourism development. Sustainability, $8(1), 100$. https://dx.doi.org/10.3390/su8010100

Puczko, L., \& Ratz, T. (2000). Tourist and resident perceptions of the physical impacts of tourism at Lake Balaton, Hungary: issues for sustainable tourism management. Journal of Sustainable Tourism, 8(6), 458-477.

Rasoolimanesh, S. M., \& Jaafar, M. (2017). Sustainable tourism development and residents' perceptions in World Heritage Site destinations. Asia Pacific Journal of Tourism Research, 22(1), 34-48. https://dx.doi.org/10.1080/10941665.2016.1175491

Su, W., Chang, L., \& Yeh, M. (2017). Developing a sustainable tourism attitude in Taiwanese residents. International Journal of Organizational Innovation, 10(1), 275-289.

Tabachnick, B. G., \& Fidell, L. (1989). Using multivariate statistics. New York: Harper and Row.

Timur, S., \& Getz, D. (2009). Sustainable tourism development: How do destination stakeholders perceive sustainable urban tourism? Sustainable Development, 17(4), 220-232. https://dx.doi.org/10.1002/sd.384

United Nations General Assembly. (2015). Transforming our world: The 2030 agenda for sustainable development. Retrieved from https://sustainabledevelopment.un.org/post2015/transformingourworld

United Nations World Commission on Environment and Development. (1987). Our common future. New York: Oxford University Press. Retrieved from http://www.un-documents.net/our-common-future.pdf

United States Travel Association. (2017). The economic impact of travel on North Carolina counties. Retrieved from https://partners.visitnc.com/economic-impact-studies 
Xu, F., \& Fox, D. (2014). Modeling attitudes to nature, tourism, and sustainable development in national parks: A survey of visitors in China and the UK. Tourism Management, 45, 142-158.

Yu, C., Chancellor, H., \& Cole, S. (2011). Measuring residents' attitudes toward sustainable tourism: A reexamination of the sustainable tourism attitude scale. Journal of Travel Research, 50(1), 57-63. https://dx.doi.org/10.1177/0047287509353189

Zhu, H., Liu, J., Wei, Z., Li, W., \& Wang, L. (2017). Residents' Attitudes towards sustainable tourism development in a historical-cultural village: Influence of perceived impacts, sense of place, and tourism development potential. Sustainability, 9(1), 1-15. https://dx.doi.org/10.3390/su9010061

\section{Copyrights}

Copyright for this article is retained by the author(s), with first publication rights granted to the journal.

This is an open-access article distributed under the terms and conditions of the Creative Commons Attribution license (http://creativecommons.org/licenses/by/4.0/). 